\title{
Effect of extrusion conditions on cassava/soybean extrudates
}

\begin{abstract}
Extrusion has been an effective technique in food process industry for production of convenience foods of diverse attributes due to its high productivity rate, very high energy efficiency, no effluents generation, e.t.c.

In the present work, the effects of extrusion parameters such as feed moisture (FM), amount of soybean (AS) and barrel temperature (BT) on water absorption index (WAI), water solubility index (WSI), trypsin inhibitors reduction (TIR) and SEC of cassava and soybean blends were investigated using a locally developed simple single screw extruder. A Box-Benkhen design of response surface methodology was used with the three input variables: FM $(16 \%, 20 \%$ and $24 \%)$, AS $(10,20$ and $30 \mathrm{~g}$ soybean $/ 100 \mathrm{~g}$ flour) and $\mathrm{BT}\left(120,145\right.$ and $\left.170^{\circ} \mathrm{C}\right)$. The experimental values of response variables WAI, WSI, TIR and SEC measured ranged from 2.43 to $3.56 \mathrm{~g}$ gel $/ \mathrm{g}$ dry sample, 0.330 to $0.447 \mathrm{~g}$ solid $/ 100 \mathrm{~g}$ sample, 62.71 to $96.21 \%$ and 2.57 to 4.24 , respectively. Regression equations describing the effect of each variable on the product responses were obtained. The product responses were most affected linearly $(\mathrm{p}<0.01)$ by changes in BT and to a lesser extent by FM and AS $(\mathrm{p}<0.1)$. A second-order polynomials obtained to predict the response variables were all significant $(\mathrm{p}<0.01)$ with high correlation coefficients (R2) between 0.895 and 0.937 showing that the model can be used to navigate the design space. In the present study, best extrudate was obtained when the FM, AS and BT were $16 \mathrm{~g}$ water $/ 100 \mathrm{~g}, 20 \mathrm{~g}$ soyabean $/ 100 \mathrm{~g}$ flour and $170^{\circ} \mathrm{C}$, respectively.
\end{abstract}

Keywords: snacks, extrusion, water absorption and solubility indices, trypsin inhibitors reduction, sensory evaluation of crispness
Volume 3 Issue I - 2016

\author{
Abioye Adekanmi Olusegun, ' Ajala Adeladun \\ Stephen,' Bolarinwa Islamiyat Folasade,' \\ Duduyemi Oladejo ${ }^{2}$ \\ 'Department of Food Science and Engineering, Ladoke Akintola \\ University of Technology, Nigeria \\ ${ }^{2}$ Department of Chemical Engineering, Lagos State University, \\ Nigeria
}

\begin{abstract}
Correspondence: Abioye Adekanmi Olusegun, Department of Food Science and Engineering, Ladoke Akintola University of Technology, P.M.B. 4000, Ogbomoso, Oyo State, Nigeria, Tel +2348080589890, Email aoabioye@lautech.edu.ng
\end{abstract}

Received: July 19, 2016 | Published: September 13, 2016

\section{Introduction}

There is always a challenge in the food process industry to develop convenience foods such as snacks, direct-expanded (puffed) and breakfast cereals of high nutritional value that will adequately meet the needs of the populace in developing countries using locally available food ingredients ${ }^{1}$ due to their snacking habits. ${ }^{2}$ The most widely consumed extruded snacks are made primarily from starchy food crops such as cereals and roots and tubers due to their good expansion characteristics. ${ }^{3-6}$ Cassava (Manihot esculenta Crantz) and its derivatives have been the base-materials for various forms of staple and snack foods in many African countries being good sources of energy. ${ }^{7}$ They contribute an important part of many consumers' daily caloric intake. ${ }^{8}$ However, they tend to be low in protein and many other nutrients and there is an increasing consumer demand for more nutritious snacks. ${ }^{9}$ Cassava is an important crop in Nigeria, where in the last few years many industries of cassava flour have been installed and the use of this ingredient in manufactured food is expanding.

Soybean (Glycine max L. Merill) protein content is high both in quality and quantity similar to the levels in meat ${ }^{10}$ which represents an advantage of this legume compared to others. ${ }^{11}$ Therefore, a lower degree of substitution of soybean in cassava flour will be needed to increase the nutritional contribution of expanded snacks from such blends without affecting consumer acceptance adversely.

Extrusion cooking can be described as a process whereby moistened biopolymers are mixed, worked and cooked into viscous, plastic-like dough through the action of flights on Archimedes' screw rotating in a tightly fitting cylindrical barrel and forced through a specially designed opening called die that gives it a definite shape. ${ }^{12,13}$ It is a continuous, high temperature, short time (HTST) process which has become a popular and economical process for formulating new cereal and legume ${ }^{14,15}$ and roots and tubers ${ }^{16}$ food blends to produce highly expanded, low-density products with unique textural properties i.e. crispiness, crunchiness e.t.c. ${ }^{17}$

Extruders thermo-mechanically cook food ingredients due to high temperature, pressure and shear stress which are generated in the screw-barrel assembly. Therefore, during extrusion cooking, the raw materials undergo many chemical and structural transformations that lead to varieties of unique products. The chemical changes that occur include conversion (gelatinization) of starch, denaturation and crosslinking of proteins, complex transformation of lipids, the stretching or restructuring of tractile components and degradation of vitamins and anti-nutritional factors in legumes, colour development and other changes. ${ }^{15,18,19}$

The water absorption and solubility indices respectively measure the extent of gelatinization (amount of damaged starch) and the volume occupied by the extrudate starch after swelling in excess water, which maintains the integrity of starch in aqueous dispersion. ${ }^{20}$ The WSI often is used as an indicator of degradation of molecular components, ${ }^{21}$ measures the degree of starch conversion during extrusion which is the amount of soluble polysaccharide released from the starch component after extrusion. Binoy et al. ${ }^{22}$ reported that WSI increased with severity of cooking. Extrusion process has also been an effective technique to improve the digestibility and remove the anti-nutrients at the same time. ${ }^{23}$ In addition to significantly increased apparent digestibility coefficients of crude protein, extrusion has effectively 
suppressed the activities of antinutritional factors especially trypsin inhibitors in full-fat soybeans for rainbow trout. ${ }^{24,25}$

Extrusion cooking being a multivariate process demands close control of many input variables such as feed moisture, feed composition, feed particle size, feed rate, barrel temperature, screw speed, screw configuration, and die geometry. These material and process variables determine the extent of macromolecular transformations during extrusion, which in turn ultimately influence the rheological properties of the food melt in the extruder and, consequently, the physical, functional and sensory characteristics of extrudates. The characteristic texture is critical ${ }^{26}$ and is important in affecting consumer acceptance. ${ }^{27}$ In order to better understand the effect of extrusion process on the characteristics of products and to obtain various extrudate with ideal structure and texture. It is therefore important to research the correlation between process and/or ingredient parameters and product properties. When many factors and interactions affect desired responses, the technique called response surface methodology (RSM) becomes one very effective tool for optimizing the process. ${ }^{28}$ The objective of this study was to investigate the effects of extrusion conditions such as FM, AS and BT on the some extrudate properties of cassava and soybean blends.

\section{Materials and methods}

\section{Materials}

A year old sweet local variety of cassava (Manihot esculenta Crantz) roots popularly known as Okoyawo among the local farmers and processors in Ogbomoso, Nigeria and its environs and soybean were sourced from the Teaching and Research Farms of the Ladoke Akintola University of Technology (LAUTECH), Ogbomoso, Nigeria and processed into flour as described by Badrie et al. ${ }^{29}$ Whole soybean seeds were dried in an air convective cabinet drier at $50^{\circ} \mathrm{C}$ until a moisture content of $7 \%$ (w.b.) was reached. The dried beans were cracked between plates of attrition mill to separate the cotyledons and hulls which were then willowed off to remove the hulls. The clean cotyledons were thereafter milled and made to pass through $1 \mathrm{~mm}$ British standard sieve. The resulting soybean flour was defatted to $8.15 \%$ final fat content from its original fat content of $18.35 \%$ using hexane solvent. The partially defatted flour was dried in the oven at $50^{\circ} \mathrm{C}$ for $24 \mathrm{~h}$ to dissolventise the residual hexane. Both the cassava and partially defatted soybean flours (CF and PDSF) were milled in a plate attrition mill to break up the clumps and made to pass through a $500 \mu \mathrm{m}$ British standard sieve and packed separately in high-density polyethylene (HDPE) bags and kept under refrigeration in a freezer until further use. All chemicals used were of analytical grade.

\section{Chemical composition of raw ingredients}

The chemical composition of the CF and PDSF were analyzed for moisture, crude protein $(\mathrm{N} \times 6.25)$, total fat, crude fiber and ash content using $\mathrm{AOAC}^{30}$ standard methods 925.10, 920.87, 920.39, 925.08 and 923.03 respectively. Carbohydrate content was determined by difference $100-(\%$ moisture $+\%$ protein $+\%$ fat $+\%$ ash $)$. Atwater energy conversion factors $17 \mathrm{~kJ} / \mathrm{g}(4 \mathrm{kcal} / \mathrm{g}), 37 \mathrm{~kJ} / \mathrm{g}(9 \mathrm{kcal} / \mathrm{g})$ and $17 \mathrm{~kJ} / \mathrm{g}(4 \mathrm{kcal} / \mathrm{g})$ were used to calculate the energy contribution of protein, fat and carbohydrate, respectively. ${ }^{30}$ Chemical composition of raw material is shown in Table 1.

\section{Extrusion process}

All blends were extruded in a $32 \mathrm{~mm}$ diameter, single screw laboratory extruder (LAUTECH, Ogbomoso). The screw was of increasing root diameter with a 2.2:1 screw compression ratio and $\mathrm{L} / \mathrm{D}$ ratio $15: 1$. The die diameter was $5.0 \mathrm{~mm}$, with a land length of $10.0 \mathrm{~mm}$ (Table 2). The inside of the barrel was grooved to ensure zero slip at the wall. The barrel was divided into four zones namely, feeding, compression, metering and pre-die sections. The feed end was cooled by water through a water jacketed cooling system to maintain the temperature below $65^{\circ} \mathrm{C}$ while the compression section was neither cooled nor heated and the metering section was electrically heated without cooling to pre-determined temperatures according to experimental design (Table 3) using a thermostatic temperature control system. A vertical screw dispenser fed the extruder from the hopper at a volumetric flowrate of approximately $250 \mathrm{~cm}^{3} / \mathrm{min}$. The independent variables in the experiments were FM of 16, 20 and 24 $\%(\mathrm{wb})$, AS of 10,20 and $30 \mathrm{~g} / 100 \mathrm{~g}$ flour and BT i.e. temperature at the metering section of $\left(120,145,170^{\circ} \mathrm{C}\right)$, respectively (Table 3$) . \mathrm{CF}$ and PDSF were mixed adjusted to predetermined moisture content levels by addition of calculated amount of water that was sprayed and admixed manually into each sample $\mathrm{w} / \mathrm{w}$ according to the experimental design (Table 3). Thereafter, each of the samples was sealed in HDPE bag and kept in refrigerator for 24 hours for equilibration and later brought out to room temperature for at least another 24hours for the sample to attain room temperature. The moisture content of the blends was ascertained before extrusion by drying the samples to a constant weight in an air-convection oven at $105^{\circ} \mathrm{C} .{ }^{30}$ All experiments were performed at screw speed of $150 \mathrm{rpm}$. Table 4 presents all the experimental runs of extrusion. Extrudates were cooled and dried at $50^{\circ} \mathrm{C}$ for 2 days, packed in HDPE bags and stored in a refrigerator at $4^{\circ} \mathrm{C}$ until further analysis.

Table I Chemical composition of raw materials $(g / / 00 g)^{*}$

\begin{tabular}{lll}
\hline Parameter & CF & PDSF \\
\hline Moisture & $9.00 \pm 0.01^{\mathrm{a}}$ & $7.33 \pm 0.28^{\mathrm{b}}$ \\
Crude fat & $0.27 \pm 0.02^{\mathrm{a}}$ & $8.15 \pm 0.18^{\mathrm{b}}$ \\
Crude protein (N x 6.25) & $1.95 \pm 0.07^{\mathrm{a}}$ & $46.11 \pm 0.29^{\mathrm{b}}$ \\
Crude fibre & $2.86 \pm 0.14^{\mathrm{a}}$ & $2.19 \pm 0.02^{\mathrm{b}}$ \\
Ash & $1.75 \pm 0.13^{\mathrm{a}}$ & $5.03 \pm 0.07^{\mathrm{b}}$ \\
Carbohydrates(by difference) & $84.17 \pm 0.13^{\mathrm{a}}$ & $31.19 \pm 0.65^{\mathrm{b}}$ \\
Energy (kcal/g) (Atwater factor) & $1569.74 \pm 4.89^{\mathrm{a}}$ & $1615.59 \pm 2.04^{\mathrm{b}}$ \\
\hline
\end{tabular}

*Means within a row with the same superscript letter are not significantly different $(\mathrm{p}<0.05)$.

All values are means of triplicate determinations \pm standard deviations.

\section{Experimental design and statistical analysis}

The effect of FM, AS and BT on some system parameters of the extrusion cooking of cassava and soybean blends was investigated using a Box Behnken design. ${ }^{31}$ The resulting experimental design included a total of 17 treatments with three levels of each factor with five replicates at the centre point to minimize the errors. Table 3 shows the levels of FM $\left(\mathrm{x}_{1}\right), \mathrm{AS}\left(\mathrm{x}_{2}\right)$ and BT $\left(\mathrm{x}_{3}\right)$ used in the experiments. From each experimental run WAI, WSI, TIR and SEC were determined as the response variables (Table $3 \&$ Table 4). Finally, a second-order polynomial regression analysis was conducted using the Design Expert 6.0 (State-Ease Inc., Minneapolis, MN, USA) to 
relate each response with the input variables by using the following response surface model with main, interaction, and quadratic terms:

$$
\begin{aligned}
Y=\beta_{0} & +\beta_{1} x_{1}+\beta_{2} x_{2}+\beta_{3} x_{3}+\beta_{12} x_{1} x_{2}+\beta_{13} x_{1} x_{3}+\beta_{23} x_{2} x_{3} \\
& +\beta_{11} x_{1}^{2}+\beta_{22} x_{2}^{2}+\beta_{33} x_{3}^{2}
\end{aligned}
$$

Applying a stepwise regression procedure, non-significant $(\mathrm{p} \geq 0.1)$ terms were deleted from the second-order polynomial and a new polynomial was recalculated to obtain a predictive model for each response variable. ${ }^{28}$ The statistical analysis system software Design Expert version 6.0.2 was used in the analysis and evaluation. The appropriateness of the model was checked using the following three methods; calculation of the coefficient of determination $\left(\mathrm{R}^{2}\right.$ value): the higher the value obtained (with a maximum of 1), the higher the fraction of variation in the response variable "explained" by the quadratic surface, a test of lack of fit: the "pure error" from the centre points was compared with the lack of fit by an F-test (significance of the test means a badly fitting model) and calculation of residuals from the regression analysis: badly fitting parts of the experimental region were reported.

\begin{tabular}{|c|c|}
\hline Parameters & Dimension \\
\hline Length of the barrel (L), mm & 470 \\
\hline Length of the feed section, mm & 110 \\
\hline Length of the compression section, $\mathrm{mm}$ & 190 \\
\hline Length of the metering section, $\mathrm{mm}$ & 130 \\
\hline Outer diameter of the barrel (D), mm & 42 \\
\hline Inner diameter of the barrel $\left(\mathrm{d}_{\mathrm{b}}\right), \mathrm{mm}$ & 32 \\
\hline Diameter of the screw $\left(D_{s}\right), m m$ & 31 \\
\hline \multicolumn{2}{|l|}{ Root diameter of the screw at the beginning } \\
\hline of compression section $\left(\mathrm{d}_{\mathrm{f}}\right), \mathrm{mm}$ & 15 \\
\hline Clearance between screw and barrel (d), mm & 0.5 \\
\hline \multicolumn{2}{|l|}{ Root diameter of the screw at the end } \\
\hline of compression section $\left(\mathrm{d}_{\mathrm{m}}\right), \mathrm{mm}$ & 25 \\
\hline Flight height in the feed section $\left(\mathrm{H}_{\mathrm{f}}\right), \mathrm{mm}$ & 8 \\
\hline Flight height in the metering section, $\mathrm{mm}$ & 3 \\
\hline Compression ratio (C.R.) & 2.2 \\
\hline Die diameter, mm & 4 \\
\hline Shear rate, $\mathrm{s}^{-1}$ & 111.7 \\
\hline Screw speed, rpm & $0-200$ \\
\hline Channel width length (W), mm & 27.63 \\
\hline Helix angle $(\theta),{ }^{\circ}$ & 10 \\
\hline Theoretical mass flowrate, $\mathrm{kg} / \mathrm{hr}$ & 5 \\
\hline Specific mechanical energy, kW.hr/kg & 0.1182 \\
\hline
\end{tabular}

Table 2 Specifications of the developed extruder
Table 3 Process variables and their levels

\begin{tabular}{llllll}
\hline Process variable & Symbol & \multicolumn{5}{c}{ Level } \\
\cline { 2 - 6 } & Original & Coded & $\mathbf{- 1}$ & $\mathbf{0}$ & $\mathbf{1}$ \\
\hline $\begin{array}{l}\text { Feed moisture }(\mathrm{g} \\
\text { water/100g) }\end{array}$ & $\mathrm{FM}$ & $x_{I}$ & 16 & 20 & 24 \\
$\begin{array}{l}\text { Amount of soybean }(\mathrm{g} \\
\text { soya/100g) }\end{array}$ & $\mathrm{AS}$ & $x_{2}$ & 10 & 20 & 30 \\
$\begin{array}{l}\text { Barrel temperature }\left({ }^{\circ} \mathrm{C}\right) \\
\text { B }\end{array}$ & $\mathrm{BT}$ & $x_{3}$ & 120 & 145 & 170 \\
\hline
\end{tabular}

\section{Determination of extrudate properties}

Water absorption index: WAI of extrudate was determined by the method of Park et al. ${ }^{32}$ Extrudate samples were ground and sieved through a $500 \mu \mathrm{m}$ sieve. Distilled water $(10 \mathrm{ml})$ at $25^{\circ} \mathrm{C}$ was placed in a tared centrifuge tube and $0.5 \mathrm{~g}$ of the extrudate was dispersed in the water. Care was taken to avoid lumping in order to produce a smooth dispersion. After standing for $30 \mathrm{~min}$ (with intermittent shaking every $5 \mathrm{~min}$ ), the sample was centrifuged (2000 Roto Silenta II, Hettich, Tuttlingen, Germany) at $1800 x$ for $15 \mathrm{~min}$. WAI was calculated in accordance with equation 2 :

$$
W A I(\%)=\frac{\text { Weight gain of gel }}{\text { Dry weight of extrudate }} \times 100
$$

Water solubility index: WSI of extrudate was determined by the method of Park et al. ${ }^{32}$ The extrudate samples were ground and sieved through $500 \mu \mathrm{m}$ sieve. Distilled water $(10 \mathrm{ml})$ at $25^{\circ} \mathrm{C}$ was placed in a tared centrifuge tube and $0.5 \mathrm{~g}$ of extrudate was dispersed in the water. Care was taken to avoid lumping in order to produce a smooth dispersion. After standing for $30 \mathrm{~min}$ (with intermittent shaking every $5 \mathrm{~min}$ ), the sample was centrifuged (2000 Roto Silenta II, Hettich, Tuttlingen, Germany) at $1800 \mathrm{xg}$ for $15 \mathrm{~min}$. The supernatant was decanted into a tared aluminum pan and dried at $105^{\circ} \mathrm{C}$ until constant weight. The weight of the gel remaining in the centrifuge tube was noted and WSI calculated In accordance with equation 3:

$$
W S I(\%)=\frac{\text { Weight of dry solids in supernatant }}{\text { Dry weight of extrudate }} \times 100
$$

Trypsin inhibitors: A sample of $1 \mathrm{~g}$ each feed formulated ingredients and extrudates were added to $5 \mathrm{ml}$ deionized water, stirred at $4^{\circ} \mathrm{C}$ overnight and centrifuged at $1500 \times \mathrm{g}$ at $4^{\circ} \mathrm{C}$ for $30 \mathrm{~min}$. The supernatant was dialyzed on a $2 \mathrm{kDa}$ MWCO at $4{ }^{\circ} \mathrm{C}$ for $20 \mathrm{~h}$. The Schwertz et al. ${ }^{33}$ method was used to determine trypsin inhibitor in the supernant, and the values were expressed in trpsin inhibitor units (TIU) per $100 \mathrm{~g}$ dry matter. The percentage of TIR during extrusion cooking was calculated from the ratio between TIA before and after extrusion.

Sensory evaluation of crispness: The method of Land et al. ${ }^{34}$ as reported by Chavez-Jauregui et al. ${ }^{35}$ was adopted for the SEC of the snack product; ballots containing an unstructured modified scale, $10.0 \mathrm{~cm}$ long was used. The panel consisted of 15 untrained persons recruited from among the students of Ladoke Akintola University of Technology, Ogbomoso. However, they were selected based on 
the administration of a screening question on their experience in accessing a popular local snack food. The crispness acceptability score was defined as the distance from the origin of the mark assigned on the scale by the panelist, relative to the end point on the scale, which was assigned as the acceptability score of a reference product (a commercial brand of snack). The samples were presented in a random sequence as pieces ( $4 \mathrm{~cm}$ in length) in 3-digit coded dishes. Every panelist assessed the reference, coded with the letter P, and was asked to indicate the crispness acceptability of the samples relative to the reference of the score on the ballot.
The evaluation was conducted in a climate-controlled sensory evaluation laboratory equipped with separately partitioned booths. The panelists cleansed their palate between samples with water. The samples were served at room temperature $\left(28 \pm 1^{\circ} \mathrm{C}\right)$ through a window and analysis was performed under normal lighting conditions. The panelists were asked to score each attribute from $0.01 \mathrm{~cm}$ (low) to $10.00 \mathrm{~cm}$ (high) for sample. Four samples were served at one session. Results were consistent among the panelists and were reproducible in different sessions.

Table 4 Effects of extrusion conditions on functional and sensory characteristics extrudates ${ }^{\mathrm{a}}$

\begin{tabular}{|c|c|c|c|c|c|c|c|}
\hline \multirow{2}{*}{ Assay No. } & \multicolumn{3}{|c|}{ Independent variables } & \multicolumn{4}{|c|}{ Dependent variables } \\
\hline & FM (x1) & AS (x2) & BT (x3) & YWAI & YWSI & YTIR & YSEC \\
\hline 1 & $16(-1)$ & $10(-1)$ & $145(0)$ & 2.79 & 0.339 & 80.45 & 3.65 \\
\hline 2 & $24(+1)$ & $10(-1)$ & $145(0)$ & 2.78 & 0.356 & 81.34 & 2.79 \\
\hline 3 & $16(-1)$ & $30(+1)$ & $145(0)$ & 2.9 & 0.406 & 64.27 & 3.98 \\
\hline 4 & $24(+1)$ & $30(+1)$ & $145(0)$ & 2.93 & 0.418 & 70.56 & 3.03 \\
\hline 5 & $16(-1)$ & $20(0)$ & $120(-1)$ & 2.43 & 0.38 & 77.13 & 3.11 \\
\hline 6 & $24(+1)$ & $20(0)$ & $120(-1)$ & 2.54 & 0.382 & 74.31 & 2.57 \\
\hline 7 & $16(-1)$ & $20(0)$ & $170(+1)$ & 2.96 & 0.447 & 78.34 & 4.24 \\
\hline 8 & $24(+1)$ & $20(0)$ & $170(+1)$ & 3.56 & 0.407 & 96.21 & 4.01 \\
\hline 9 & $20(0)$ & $10(-1)$ & $120(-1)$ & 2.5 & 0.33 & 67.87 & 2.68 \\
\hline 10 & $20(0)$ & $30(+1)$ & $120(-1)$ & 2.87 & 0.354 & 62.71 & 2.98 \\
\hline 11 & $20(0)$ & $10(-1)$ & $170(+1)$ & 3.11 & 0.401 & 84 & 3.7 \\
\hline 12 & $20(0)$ & $30(+1)$ & $170(+1)$ & 3.17 & 0.439 & 85.93 & 3.82 \\
\hline 13 & $20(0)$ & $20(0)$ & $145(0)$ & 2.63 & 0.361 & 71.94 & 3.23 \\
\hline 14 & $20(0)$ & $20(0)$ & $145(0)$ & 2.7 & 0.359 & 71.62 & 3.31 \\
\hline 15 & $20(0)$ & $20(0)$ & $145(0)$ & 2.48 & 0.364 & 71.95 & 3.34 \\
\hline 16 & $20(0)$ & $20(0)$ & $145(0)$ & 2.6 & 0.366 & 72.05 & 3.51 \\
\hline 17 & $20(0)$ & $20(0)$ & $145(0)$ & 2.67 & 0.361 & 70.54 & 3.42 \\
\hline
\end{tabular}

${ }^{\text {aBox }}$ and Behnken with three levels and three factors, I7 experiments; All values are means of triplicate determinations bDoes not necessarily correspond to the order of experiment.

'FM, feed moisture (g water/l00g); AS, amount of soybean (g soyabean/l00g); BT, barrel temperature $\left({ }^{\circ} \mathrm{C}\right)$. Values in parentheses are the coded levels. ${ }^{\mathrm{d}} Y_{\text {WAI, }}$ water absorption index (g gel/g dry sample); $Y_{\text {WSI, }}$ water solubility index (g solids/I00g original solids); $Y_{T I R}$, trypsin inhibitor reduction (\%); $Y_{S E C,}$ sensory evaluation of crispness

\section{Results and discussion}

\section{Water absorption index, $\mathbf{Y}_{\text {WAI }}$}

The WAI give insight to the extent of gelatinization of starch in the feed ingredient generally by measuring the amount of water absorbed by starch granules after swelling in excess of water originally present in the product. ${ }^{36}$ WAI depends on the availability of hydrophilic groups which bind water molecules and the gel-forming capacity of the macromolecules involved. ${ }^{37}$ Dispersion is observed to increase in proportion to the degree of starch damage due to gelatinization and extrusion-induced fragmentation, that is, molecular weight reduction of amylose and amylopectin molecules. ${ }^{38}$ The effect of input (independent) variables such as FM, AS and BT on WAI of the extrudates are as presented in Table 4.
Analysis of variance showed that WAI was significantly dependent on the positive linear term of BT and the quadratic terms of AS and BT $(p<0.1)$. No interaction of all the variables affected the response $(p \geq 0.10$ ). It was observed on response surface plots (Figure 1 ) that there was significant quadratic effect of AS and BT on WAI resulting in a curved surface. The resulting polynomial after removal of the nonsignificant ( $\mathrm{p} \geq .1)$ terms using coded variables resulted in equation 4 :

$$
Y_{W A I}=2.66+0.31 x_{3}+0.14 x_{2}^{2}+0.16 x_{3}^{2}
$$

The regression model was significant $(\mathrm{p}<0.05)$. Moreover, the model did not show significant lack-of-fit $(\mathrm{p}>0.05)$ relative to the pure error and a good correlation with the actual measurements as shown in Figure 5 with corelation coefficient of 0.895 , suggesting that the second-order polynomial model correlated experimental WAI 
results well which varied from 2.11 to $3.56(\mathrm{~g} / \mathrm{g})$ as shown in Table 4. Therefore, the model can be used to navigate the design space.

As the concentration of AS and BT increased, WAI continuously increased at all levels of FM (Figure 1). Protein denaturation, starch gelatinization and swelling of fiber, which took place during extrusion, could all Table 5: Regression coefficients and analyses of variance of second-order polynomial models showing relationships among product characteristics and input variables be responsible for the increased WAI of extruded products. Another school of thought suggested that low WAI at low temperature indicated restricted water availability to the starch granules due to their more compact structure. ${ }^{39}$ However, when the temperature increased, amylose and amylopectin separated, forming an expandable matrix which resulted in a higher water-holding ability that agreed well with reported data in the literature. ${ }^{40}$

It is also evident on the response surface curves (Figure 1) that WAI increased marginally ( $\mathrm{p} \geq 0.1)$ with FM at all levels of AS and BT tested in the experiments. This observation appears to contradict the behavior of WAI and suggests that at high FM, starch granules become less susceptible to rupture because the water tends to act as a lubricant resulting in decreased levels of gelatinization and dextrinization. ${ }^{41,42}$ However, the general trend of results from this study has been reported by other investigators which suggested that WAI for cassava and jatoba flour extrudates containing very high levels of starch and fiber contents showed the opposite behavior, i.e. increasing pattern of WAI with increase in moisture content. ${ }^{39}$

\section{Water solubility index, $\mathbf{Y}_{\text {wsI }}$}

The WSI determines the amount of soluble polysaccharide released from the starch granules after addition of excess water and is often used as an index of degradation of molecular components which is related to dextrinization. ${ }^{36,42,43}$ The regression analysis performed in Table 5 indicated that AS and BT had positive linear effects on WSI $(p<0.05)$ followed by the quadratic effects of FM and BT $(p<0.05)$. The response surface plots in Figure 2 indicated that WSI increased with increasing AS and BT. The resulting polynomial after removal of non-significant $(\mathrm{p} \geq 0.1)$ terms resulted in equation 5 .

$$
Y_{W S I}=0.36-0.001 x_{1}+0.024 x_{2}+0.031 x_{3}+0.02 x_{1}^{2}+0.021 x_{3}^{2}
$$

Table 5 shows that the regression model for WSI was highly significant $(\mathrm{p}<0.01)$. Although, the model did show a significant lackof-fit $(\mathrm{p}<0.05)$, however, Figure 5 shows good relationship between the actual and predicted model with reasonable high $\mathrm{R}^{2}=0.908$. Therefore, the model can be used to navigate the design space.

Rising temperature increased the severity of thermal treatment in the extruder, which consequently raised WSI (Figure 2). Ralet et al. ${ }^{44}$ reported that wheat bran increased its water uptake after extrusion. This could be as a result of the disruption of covalent or non-covalent bonds in the carbohydrate and protein moieties, leading to smaller, more soluble molecular fragments. ${ }^{45,46}$ These observations confirm similar findings reported for starch-based extrudates obtained either using single or twin screw extrusion..$^{77,48}$ Dextrinization is well known as the predominant mechanism of starch degradation during low moisture extrusion. ${ }^{37}$ Therefore, the decreasing trend of WSI with FM was expected and in agreement with previous reports. ${ }^{43,49}$

\section{Trypsin inhibitors reduction, $\mathbf{Y}_{\mathrm{TIR}}$}

Regression analysis of results of Table 5 from the study showed that FM and BT had positive linear effects $(p<0.1$ and $p<0.05)$, while the AS had negative linear effects $(p<0.1)$ on TIR followed by the quadratic effects $(\mathrm{p}<0.1)$ of $\mathrm{FM}$ and $\mathrm{BT}$ and an interaction effect $(\mathrm{p}<0.05)$ of FM and BT as the most significant influence. It was observed on the response surface plots of Figure 3 that increased moisture and temperature induced a dramatic decrease of TIR at different levels of the AS tested. The recorded coefficient of determination $\left(\mathrm{R}^{2}\right)$ was 0.900 and the polynomial for this variable resulted in equation 6 :

$$
Y_{\text {TIR }}=71.62+2.74 x_{1}-3.77 x_{2}+7.77 x_{3}+5.25 x_{1} x_{3}+4.49 x_{1}^{2}+5.46 x_{3}^{2}
$$

Low anti-trypsin activity was recorded for extrudates under all experimental conditions, which indicated that high temperature and high mechanical stress developed during extrusion processing inactivated substances responsible for these factors. Reported reduction values after the extrusion of bean $\mathrm{s}^{50,51}$ have usually been $95 \%$, at extrusion temperature range of $120-150^{\circ} \mathrm{C}$, which was also achieved in the extruder, though at higher temperature. Temperatures recorded in these experiments reached $170^{\circ} \mathrm{C}$, which was a more severe process and destroyed the trypsin inhibitors to the expected level. According to Harper, ${ }^{52}$ a reduction of $70 \%$ or more in antitrypsin activity in beans was indicative of nutritive quality.

The nutritional quality of legumes and legume-based blends are often constrained and limited by the presence of anti-nutritional factors that hamper either nutrient digestion or its utilization. The reduction or inactivation of these factors by means of processing technology requires knowledge of the type, distribution, chemical reactivity and thermal sensitivity of the anti-nutritional factors. ${ }^{53}$ Despite the high thermal stability of trypsin inhibitors, the combination of high heat and high humidity in the extrusion process considerably reduced their inhibitory activity in the SCEs (62.71-96.21\%; Table 4.10). These results confirm those found by Alonso, Aguirre et al. ${ }^{54}$ Anton Fulcher et al. ${ }^{6}$ Values of residual trypsin inhibitors were lower than those found by Toledo et al. ${ }^{55}$ in soybean seeds after irradiation. Haddad et al. ${ }^{56}$ also recorded higher trypsin inhibitor values in raw soybean seeds as El-Hady et al. ${ }^{23}$ in unsoaked and soaked common bean, and Genovese et al. ${ }^{57}$ in soybean products.

\section{Sensory evaluation of crispness}

The multiple regression analysis performed for SEC in this study showed significant $(p<0.05)$ linear effects of all independent variables with the exception of the AS, which recorded the least significance $(p<0.1)$ (Table 5). The coefficient of determination $\left(R^{2}\right)$ was 0.937 and the polynomial fitted for this variable resulted in equation 4.8:

$$
Y_{S E C}=3.37-0.32 x_{1}+0.12 x_{2}-0.55 x_{3}
$$

Response surface curves generated from this polynomial are presented in Figure 4. The regression model for SEC was highly significant $(p<0.05)$ indicating that the second-order polynomial model correlated well with the recorded data. Therefore, the model can be used to navigate the design space, though with a reasonable 
significant lack of fit $(\mathrm{p}<0.05)$. The maximum SEC of the CSEs was recorded at $16 \%(\mathrm{wb})$ of $\mathrm{FM}, 20 \% \mathrm{AS}$ and $170{ }^{\circ} \mathrm{C} \mathrm{BT}$ (assay number 7, Table 4.8), at which maximum scores were assigned by panelists, indicating higher acceptance of the texture when compared to the standard. These conditions are hence recommended for the production of snacks from a combination of CF and PDSF.

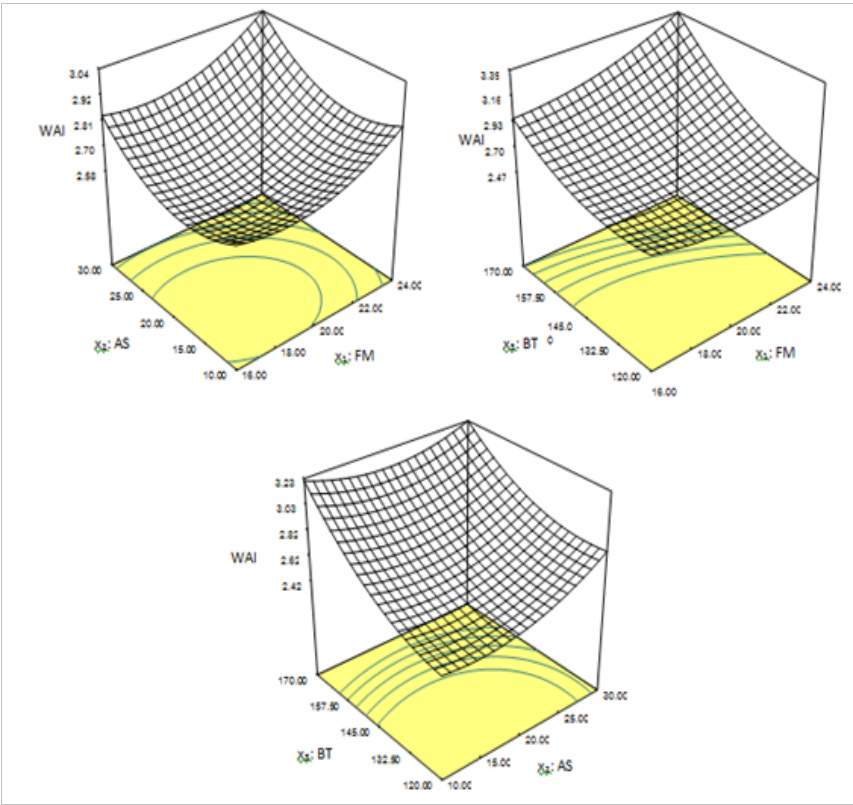

Figure I Response surface for the effect of input variables and their interactions on WAI of extrudates.
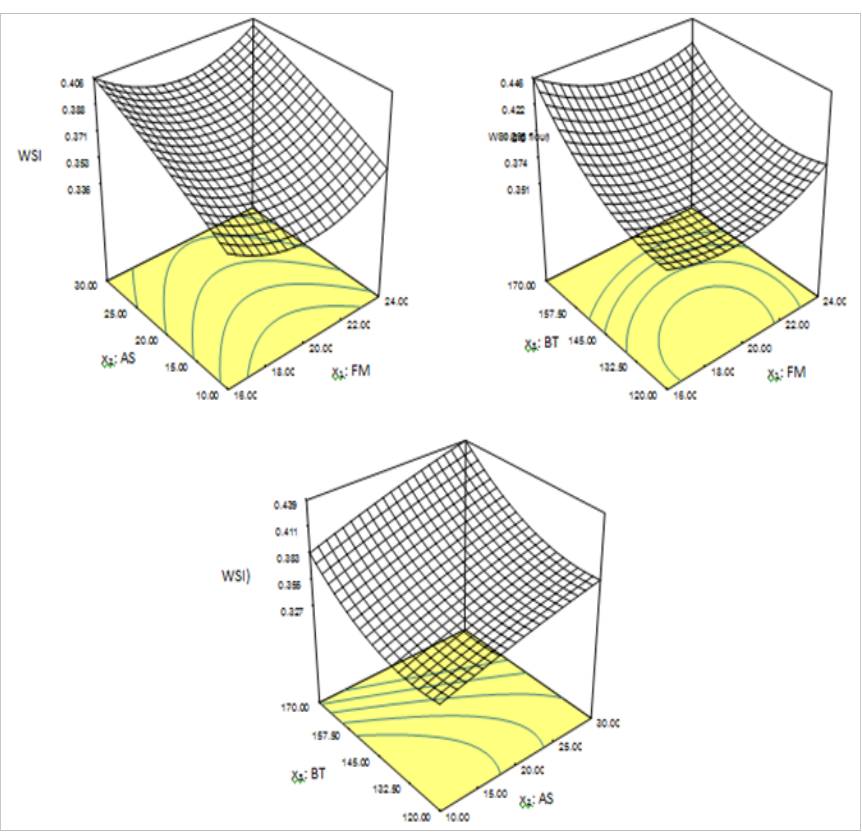

Figure 2 Response surface for the effect of input variables and their interactions on WSI of extrudates.
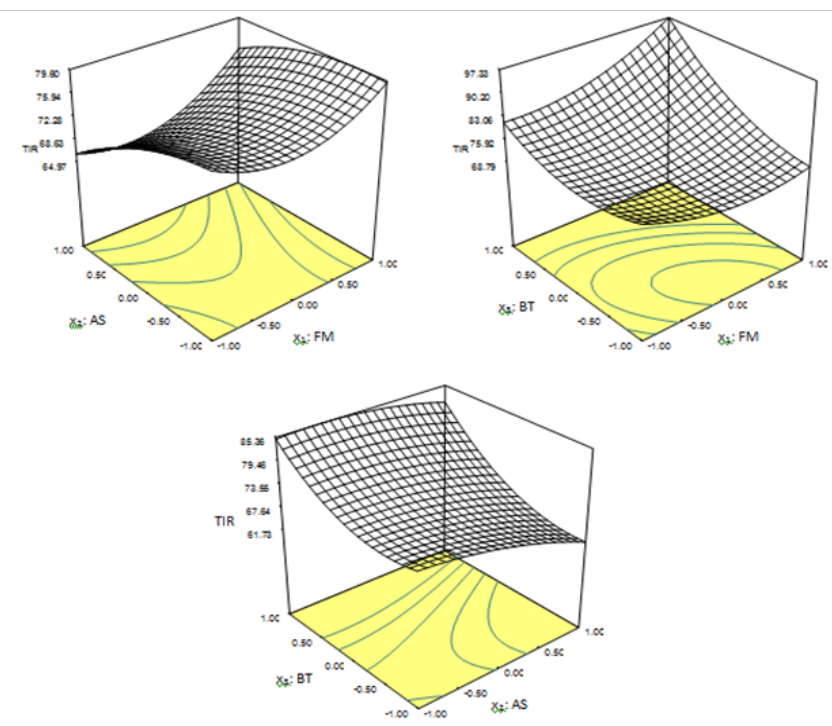

Figure 3 Response surface for the effect of input variables and their interactions on TIR.

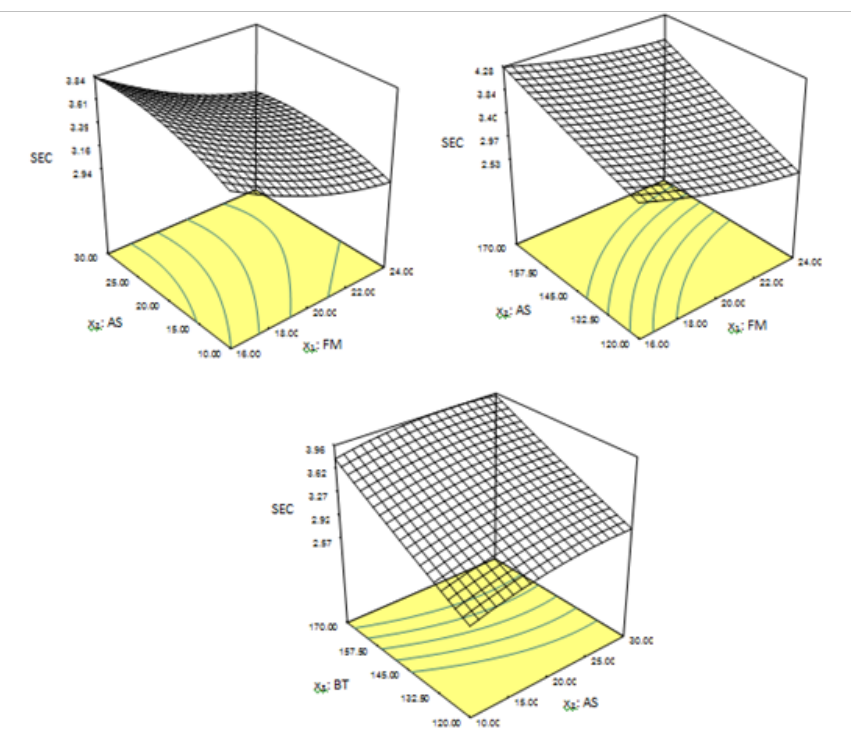

Figure 4 Response surface for the effect of input variables and their interactions on sensory acceptability of texture.
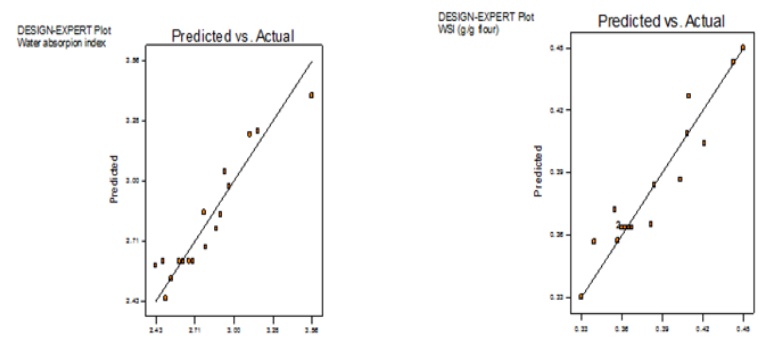


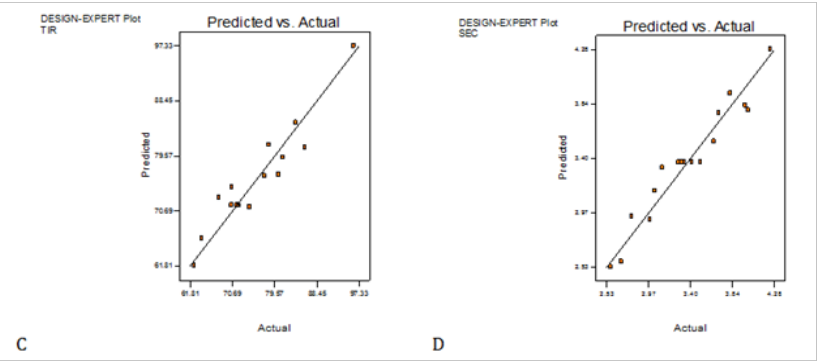

Figure 5 Predicted value versus actual measurements of extrudate characteristics.

Table 5 Regression coefficients and analyses of variance of second-order polynomial models showing relationships among product characteristics and input variables

\begin{tabular}{|c|c|c|c|c|}
\hline Coefficient & $\mathbf{Y}_{\mathrm{WAI}}$ & $\mathbf{Y}_{\text {wSI }}$ & $\mathbf{Y}_{\mathrm{TIR}}$ & $\mathbf{Y}_{\mathrm{SEC}}$ \\
\hline \multicolumn{5}{|l|}{ Intercept } \\
\hline$\beta_{0}$ & $2.66 * *$ & $36.22 * * *$ & $71.62 * * *$ & $3.27 * * *$ \\
\hline \multicolumn{5}{|l|}{ Linear } \\
\hline$\beta_{1}$ & $0.091^{+}$ & $-0.097^{+}$ & $2.74 *$ & $-0.32 * * *$ \\
\hline$\beta_{2}$ & $0.086^{+}$ & $2.37 * * *$ & $-3.77^{*}$ & $0.12 *$ \\
\hline$\beta_{3}$ & $0.31 * * *$ & $3.09 * * *$ & $7.77 * * *$ & $0.55 * * *$ \\
\hline \multicolumn{5}{|l|}{ Quadratic } \\
\hline$\beta_{11}$ & $0.097^{+}$ & $2.01 * *$ & $4.49 *$ & $0.089^{+}$ \\
\hline$\beta_{22}$ & $0.14^{*}$ & $-2.80^{+}$ & $-1.95^{+}$ & $-0.099^{+}$ \\
\hline$\beta_{33}$ & $0.16^{*}$ & $2.14 * *$ & $5.46^{* *}$ & $0.022^{+}$ \\
\hline \multicolumn{5}{|l|}{ Interactions } \\
\hline$\beta_{12}$ & $0.01^{+}$ & $-0.13^{+}$ & $1.35^{+}$ & $-0.023^{+}$ \\
\hline$\beta_{13}$ & $0.12^{+}$ & $-1.05^{+}$ & $5.25^{* *}$ & $0.077^{+}$ \\
\hline$\beta_{23}$ & $-0.078^{+}$ & $-0.35^{+}$ & $1.77^{+}$ & $-0.045^{+}$ \\
\hline \multicolumn{5}{|c|}{$\begin{array}{l}\text { Test for model } \\
\text { adequacy }\end{array}$} \\
\hline $\mathrm{R}^{2}$ & 0.895 & 0.908 & 0.9 & 0.937 \\
\hline $\begin{array}{l}\mathrm{p} \text {-value for } \\
\text { model }\end{array}$ & 0.0105 & 0.0067 & 0.0001 & 0.0019 \\
\hline $\begin{array}{l}\text { p- value for } \\
\text { model lack- } \\
\text { of-fit }\end{array}$ & 0.0777 & 0.0006 & 0.0004 & 0.0385 \\
\hline
\end{tabular}

*Significant at $\mathrm{p}<0.1$ level; **significant at $\mathrm{p}<0.05$ level; ***significant at $\mathrm{p}<0.0$ I level.

+ Not significant.

\section{Conclusion}

Change of extrusion conditions, FM, AS and BT, affected the characteristics of the cassava-based snack. The extrudates that exhibited high WAI and WSI, TIR and SEC which are generally the required characteristics of extruded snacks which were obtained at low feed moisture $(16 \%)$, high barrel temperature $\left(170^{\circ} \mathrm{C}\right)$ and average level of PDSF $(20 \%)$. It was demonstrated that, by properly selecting extrusion processing conditions and ingredient composition, cassava and soybean flour blends will produce nutritious snack products that have desirable functional and fairly good texture (crispness) attributes.

\section{Acknowledgements}

None.

\section{Conflict of interest}

The author declares no conflict of interest,

\section{References}

1. Asare EK, Sefa-Dedeh S, Sakyi-Dawson E, et al. Application of response surface methodology for studying the product characteristics of extruded rice-cowpea-groundnut blends. International Journal of Food Sciences and Nutrition. 2004;55(5):431-439.

2. Nicklas TA, Yang SJ, Baranowski T, et al. Eating patterns and obesity in children: the Bogalusa heart study. American Journal of Preventive Medicine. 2003;25(1):9-16.

3. Fernandez-Gutierrez JA, Martin-Martinez ES, Martinez-Bustos F, et al. Physicochemical properties of Casein-starch interaction obtained by extrusion process. Starch-Stärke. 2004;56 (5):190-198.

4. Yagmur C, Ainsworth P, Ibanoglu S, et al. Expansion characteristics of a nutritious extruded snack food using response surface methodology. European Food Research Technology. 2004;218(5):474-479.

5. Singh S, Gamlath S, Wakeling L. Nutritional aspects of food extrusion: A review. International Journal Food Science and Technology. 2007;42:916-929.

6. Anton AA, Fulcher RG, Arntfield SD. Physical and nutritional impact of fortification of corn starch-based extruded snacks with common bean (Phaseolus vulgaris L.) flour: Effects of bean addition and extrusion cooking. Food Chemistry. 2009;113(4):989-996.

7. Bokanga M. Cassava: Opportunities for the food, feed and other industries in Africa. In: Treche, et al. editors. Transformation Alimentaire du Manioc. T Orstom, Canada; 1995. p. 557-569.

8. Weinstock CP. The "grazing" of America: A guide to healthy snacking. FDA Consumer. 1989;3(2):8.

9. Agriculture and Agri-Food Canada. The Canadian snack food industry; 2008.

10. de Almeida Costa, GE, da Silva Queiroz-Monici K, Machado Reis SMP, et al. Chemical composition, dietary fibre and resistant starch contents of raw and cooked pea, common bean, chickpea and lentil legumes. Food Chemistry. 2006;94(3):327-330.

11. Messina MJ. Legumes and soybeans: Overview of their nutritional profile and health effects. American Journal of Clinical Nutrition. 1999;70(3 suppl):439S-450S.

12. Harper JM. Food extrusion. CRC Crit Rev Food Sci Nutr. 1979;11(2):155215.

13. Milan-Carrillo J, Reyes-Moreno J, Camacho-Hernandez C, et al. Optimisation of extrusion process to transform hardened chickpeas (Cicer arietinum L) into a useful product. Journal of Science for Food and Agriculture. 2002;82:1718-1728.

14. Martin-Cabrejas MA, Jaime L, Karanja C, et al. Modification to physicochemical and nutritional properties of hard-to-cook beans (Phaseolus vulgaris L) by extrusion cooking. Journal Agriculture and Food Chemistry. 19999;47(3):1174-1182. 
15. Iwe MO, van Zuilichem DJ, Ngoddy PO, et al. Amino acid and protein dispersibility index (PDI) of mixtures of extruded soy and sweet potato flours. LWT Food Sci Technol. 2001;34(2):71-75.

16. Filli KB, Nkama I, Abubakar UM, et al. Influence of extrusion variables on some functional properties of extruded millet-soybean for the manufacture of 'fura': A Nigerian traditional food. African Journal of Food Science. 2010;4(6):342-352.

17. Ilo S, Berghoper E. Kinetics of lysine and other amino acids loss during extrusion cooking of maize grits. Journal of Food Science. 2003;68(2):496-501.

18. Mouquet C, Salvingnol B, van Hoan N, et al. Ability of a "very low-cost extruder" to produce instant flours at a small scale in Vietnam. Food Chemistry. 2003;82(2):249-255.

19. Qing-Bo D, Ainsworth P, Tuker G, et al. The effect of extrusion conditions on the physicochemical properties and sensory characteristics of rice based expanded snacks. Journal of Food Engineering. 2005;66(3):284 289.

20. Kirby AR, Ollett AL, Parker R, et al. An experimental study of screw configuration effects in the twin screw extrusion cooking of maize grits. Journal of Food Engineering. 1988;8(4):247-272.

21. Binoy KG, Aaron JO, Gour SC. Reverse screw element(s) and feed composition effects during twin-screw extrusion of ice flour and fish muscle blends. Journal of Food Science. 1996;61(3):590-595.

22. Abd El-Hady EA, Habiba RA. Effect of soaking and extrusion conditions on antinutrients and protein digestibility of legume seeds. LWT Food Sci Technol. 2003;36(3):285-293.

23. Cheng ZJ, Hardy RW. Effects of extrusion and expelling processing and microbial phytase supplementation on apparent digestibility coefficients of nutrients in full-fat soybeans for rainbow trout (Oncorhynchus mykiss). Aquaculture. 2003;218(1-4):501-514.

24. Wang Y, Li D, Wang LJ, et al. Optimization of extrusion of flaxseeds for in vitro protein digestibility analysis using response surface methodology. Journal of Food Engineering. 2008;85(1):59-64.

25. Clark JP. Texturization processes in the cereal foods industry. Food Technology. 1986;40:91-93.

26. Ranhotra GS, Vetter JL. Foods considered for nutrient addition: Snacks and confectioneries. In: Bauernfeind JC, et al. editors. Nutrient addition to food. Food and Nutrition Press; 1991. p. 319-345.

27. Montgomery DC. Design and analysis of experiments. 6th ed. USA: John Wiley and Sons Inc; 2005.

28. Badrie N, Mellowes WA. Effect of extrusion variables on cassava extrudates. Journal of Food Science. 1991;56:1334-1337.

29. AOAC. Official methods of analysis of the Association of Official Analytical Chemists. 15th ed. USA: Washington DC; 1995.

30. Box GEP, Behnken DW. Some new three level designs for the study of quantitative variables. Technometrics.1960;2:455-475.

31. Park J, Rhee KS, Kim BK, et al. High-protein texturized products of defatted soy-flour, corn starch and beef: Shelf life, physical and sensory properties. Journal of Food Science. 1993;58(1):28-32.

32. Schwertz GW, Takenaka Y. A spectophotometric determination of trypsin and chymotrypsin activity. Biochemistry and Biophysics Acta. 1995;16(4):571-575.

33. Land DG, Shepherd R. Scaling and ranking methods. In: Piggott JR editor. Sensory analysis of foods. New York, USA: Elsevier Science Publishing Co; 1988. p. 155-167.
34. Chavez-Jauregui RN, Silva MEMP Areas JAG. Extrusion cooking process for amaranth Amaranthus caudatus L.). Journal of Food Science. 2000;65(6):1009-1015.

35. van den Einde R, Bolsius A, van Soest J, et al. The effect of thermomechanical treatment on starch breakdown and the consequences for the process design. Carbohydrate Polymers. 2003;55(11):57-63.

36. Gomez MH, Aguilera JM. Changes in the starch fraction during extrusion cooking of corn. Journal of Food Science. 183;48(2):378-381.

37. Rayas-Duarte P, Majewska K, Doetkott C. Effect of extrusion process parameters on the quality of buckwheat flour mixes. Cereal Chemistry. 1998;75(1):338-345.

38. Chang YK, Silva MR, Gutkoski LC, et al. Development of extruded snacks using jatobá (Hymenaea stigonocarpa Mart) flour and cassava starch blends. Journal of the Science of Food and Agriculture. 1998;78(1):59-66.

39. Kokini JL, Lai LS, Chedid LL. Effect of starch structure on starch rheological properties. Journal of Food Technology. 1992;46(6):124-139.

40. Berglund PT, Fastnaught CE, Holm ET. Physicochemical and sensory evaluation of extruded high-fibre barley cereals. Cereal Chemistry. 1994;71(1):91-95.

41. Huang DP. New perspectives on starch and starch derivatives for snack applications. Cereal Foods World. 1995;40:528-531.

42. Ding QB, Ainsworth P, Tucker G, et al. The effect of extrusion conditions on the physicochemical properties and sensory characteristics of ricebased expanded snacks. Journal of Food Engineering. 2005;66(3):283289.

43. Drago SR, Velasco-Gonz'alez OH, Torres RL, et al. Effect of the extrusion on functional properties and mineral dialyzability from Phaseolus vulgaris bean flour. Plant Foods for Human Nutrition. 2007;62(2):s43-s48.

44. Ralet MC, Thibault JF, Della-Valle G. Influence of extrusion cooking on the physico-chemical properties of wheat bran. Journal of Cereal Science. 1990;11(3):249-259.

45. Wang S, Casulli J, Bouvier JM. Effect of dough ingredients on apparent viscosity and properties of extrudates in twin-screw extrusion cooking. International Journal of Food Science and Technology. 1993;28(5):465479.

46. Ding QB, Ainsworth P, Plunkett A, et al. The effect of extrusion conditions on the functional and physical properties of wheat-based expanded snacks. Journal of Food Engineering. 2006;73(2):142-148.

47. Kadan RS, Bryant RJ Pepperman AB. Functional properties of extruded rice flours. Food Science. 2003;68(5):1669-1672.

48. Hernandez-Diaz JR, Quintero-Ramos A, Barnard J Balandran-Quintana RR. Functional properties of extrudates prepared with blends of wheat flour/pinto bean meal with added wheat bran. Food Science and Technology International. 2007;13(4):301-308.

49. Harper JM, Jansen GR. Production of nutritious precooked foods in developing countries by low-cost extrusion technology. Food Review International. 1985;1:27-97.

50. Noguchi A. Food processing activities in Japan on the use of twin-screw extruders. Tsukuba, Japan: Report of the National Food Research Institute; 1986. $40 \mathrm{p}$.

51. Harper JM. Personal communication. Chihuahua, Chihuahua, México; 1993.

52. Marzo F, Alonso R, Urdaneta E, et al. Nutritional quality of extruded kidney bean (Phaseolus vulgaris, L. var. Pinto) and its effects on growth and skeletal muscle nitrogen fractions in rats. Journal of Animal Science. 2002;80(4):875-879. 
53. Alonso R, Aguirre A, Marzo F. Effects of extrusion and traditiona processing methods on antinutrients and in vitro digestibility of protein and starch in faba and kidney beans. Food Chemistry. 2000;68(2):159-165.

54. Toledo TCF, Canniatti-Brazaca SG, Arthur V, et al. Effects of gamma radiation on total phenolics, trypsin and tannin inhibitors in soybean grains. Journal of Radiation Physics and Chemistry. 2007;76(10):16531656.
55. Haddad J, Allaf K. A study of the impact of instantaneous controlled pressure drop on the trypsin inhibitors of soybean. Journal of Food Engineering. 2007;79(1):353-357.

56. Genovese MI, Lajolo FM. Atividade inibitoria de tripsin em produtos derivadosde soja (Glycine max) consumidos no Brasil. Cienc Tecnol Aliment. 1998;18:309-312. 